\title{
ANALISIS PENYUSUNAN ANGGARAN PADA KANTOR KELURAHAN KARAME KECAMATAN SINGKIL KOTA MANADO TAHUN ANGGARAN 2014
}

\author{
Judisty Kaumbang \\ Sifrid S. Pangemanan \\ Heince R. N. Wokas \\ Fakultas Ekonomi Dan Bisnis Jurusan Akuntansi \\ Universitas Sam Ratulangi \\ Email : judistykaumbang@gmail.com
}

\begin{abstract}
The budget is estimated to be achieved over a certain period set forth in the financial measures. Stage Budgeting is the first stage of the budgeting process. At this stage, usually by the executive budget plan that will implement the budget. The purpose of this study was to determine the budget formulation process at the Village Office KarameSingkil District of Manado City budget year 2014. The method used is descriptive and data obtained through field studies. The results were obtained at the Village Office KarameSingkil District of Manado City has implemented the budget process in accordance with Regulation No.27 of 2013 on guidelines for the budgeting of fiscal year 2014. At the Village Office KarameSingkil District of Manado City budget formulation for 2014 was in accordance with Regulation No. 27, 2013. the preparation of the budget at the Village Office KarameSingkil District of Manado City has been presented in the form of local budget cycle.
\end{abstract}

Keywords: analysis, making, budget

\section{PENDAHULUAN}

\section{Latar Belakang}

Pemerintah adalah suatu organisasi yang diberi kekuasaan untuk mengatur kepentingan bangsa dan negara. Lembaga pemerintah dibentuk umumnya untuk menjalankan aktivitas layanan terhadap masyarakat luas dan sebagai organisasi nirlaba yang mempunyai tujuan bukan untuk mencari keuntungan tetapi untuk menyediakan layanan dan kemampuan meningkatkan layanan tersebut di masa yang akan datang. Tujuan yang akan dicapai biasanya ditentukan dalam bentuk kualitatif, misalnya meningkatkan kenyamanan dan keamanan, mutu pendidikan, kesehatan maupun keimanan.

Seiring dengan upaya mewujudkan good governance maka terjadilah reformasi atas pengelolaan keuangan. Sebelum berlakunya paket undang-undang di bidang keuangan negara, ketentuan perundang-undangan yang berlaku mengharuskan pertanggungjawaban pengelolaan keuangan negara dalam bentuk perhitungan anggaran negara/daerah. Wujud laporan ini hanya menginformasi aliran kas Anggaran Pendapatan dan Belanja Daerah (APBD) sesuai dengan format anggaran yang disahkan oleh legislatif, tanpa menyertakan informasi tentang posisi kekayaan dan kewajiban pemerintah.

Pengelolaan keuangan sangat penting dilakukan di Kantor Kelurahan Karame Kecamatan Singkil Kota Manado agar anggaran ditetapkan untuk membiayai semua kebutuhan program yang dijalankan serta realisasinya dapat sesuai dengan anggaran yang ditetapkan. Dalam kaitannya dengan penetapan anggaran tidak terlepas dari biaya-biaya yang berhubungan dengan program yang akan dilakukan oleh Kantor Kelurahan Karame Kecamatan Singkil Kota Manado. Semua program membutuhkan biaya untuk menunjang program dari Kantor Kelurahan Karame Kecamatan Singkil Kota Manado, untuk itu dibutuhkan pengalokasian biaya yang benar agar menghasilkan anggaran yang sesuai untuk kebutuhan tersebut. 
Merupakan suatu tantangan bagi pemerintah Kota Manado untuk dapat memenuhi kewajiban dalam hal penyusunan anggaran yang baik dan benar sebagaimana yang tercantum dalam Peraturan Menteri Dalam Negeri Nomor 27 Tahun 2013 tentang pedoman penyusunan anggaran pendapatan dan belanja daerah tahun anggaran 2014 karena ini diperlukanagar anggaran dapat digunakan dengan efisien dan efektif, sesuai dengan program dan sasaran penyusunan anggaran. Selain itu, dengan adanya Permendagri No. 27 Tahun 2013 dapat mengarahkan penyusunan anggaran di pemerintahan Kota Manado ke arah yang lebih baik, dengan tujuan dan sasaran yang jelas dan tepat demi pembangunan daerah dan kesejahteraan masyarakat.

Berdasarkan latar belakang masalah diatas, maka penulis tertarik mengadakan penelitian dengan judul "Analisis Penyusunan Anggaran pada Kantor Kelurahan Karame Kecamatan Singkil Kota Manado Tahun Anggaran 2014".

\title{
Tujuan Penelitian
}

Tujuan penelitian adalah untuk mengetahui proses penyusunan anggaran di Kantor Kelurahan Kecamatan Singkil Kota Manado.

\section{TINJAUAN PUSTAKA}

\begin{abstract}
Akuntansi
Suwardjono (2013:10) menyatakan bahwa akuntansi sebagai kegiatan penyediaan jasa mengisyaratkan bahwa akuntansi yang akhirnya harus diterapkan untuk merancang dan menyediakan jasa berupa informasi keuangan harus bermanfaat untuk kepentingan sosial dan ekonomi negara tempat akuntansi diterapkan.Standar Akuntansi Pemerintahan (2010:4) menyatakan bahwa akuntansi adalah proses pengidentifikasian, pencatatan, pengukuran, klasifikasian, pengikhtisaran transaksi dan kejadian keuangan, penyajian laporan serta penginterprestasian atas hasilnya. Halim dan Kusufi (2012:36) mendenifisikan akuntansi sebagai suatu proses pengidentifikasian, pengukuran, pencatatan, dan pelaporan transaksi ekonomi (keuangan) dari suatu organisasi/entitas yang dijadikan sebagai informasi dalam rangka pengambilan keputusan ekonomi oleh pihak-pihak yang memerlukan.
\end{abstract}

\section{Akuntansi Pemerintahan}

Deddi, Iswahyudi dan Maulidah (2012:1) menyatakan bahwa Akuntansi Pemerintahan merupakan bidang ilmu akuntansi yang saat ini sedang berkembang pesat. Tuntutan transparasi dan akuntabilitas publik atas dana-dana masyarakat ysng dikelolah pemerintah memunculkan kebutuhan atas penggunaan akuntansi dalam mencatat dan melaporkan kinerja pemerintahan. Akuntansi pemerintahan mengkhususkan dalam pencatatan dan pelaporan transaksi-transaksi yang terjadi di badan pemerintahan. Akuntan pemerintahan menyediakan laporan akuntansi tentang aspek kepengurusan dari administrasi keuangan Negara. Di samping itu, bidang ini meliputi pengendalian atas pengeluaran melalui anggaran negara, termasuk kesesuiannya dengan UU yang berlaku.

\section{Anggaran Pemerintah}

Hariadi, Yanuar dan Icuk (2010:7) menyatakan anggaran adalah estimasi yang akan dicapai selama periode tertentu yang dinyatakan dalam ukuran finansial. Nordiawan dan Hertianti (2010:69) menyatakan anggaran dapat dikatakan sebagai pernyataan estimasi kinerja yang hendak dicapai selama periode waktu tertentu dalam ukuran finansial. Mahsun (2013:145) menyatakan bahwa anggaran adalah perencanaan keuangan untuk masa depan yang pada umumnya mengcangkup jangka waktu satu tahun dan dinyatakan dalam satuan moneter.Deddi, et al. (2012: 19) menyatakan bahwa anggaran sebagai pernyataan mengenai estimasi kinerja yang hendak dicapai selama periode waktu tertentu dalam ukuran finansial. Pembuatan anggaran dalam organisasi sektor publik, terutama pemerintah merupakan sebuah proses yang cukup rumit dan mengandung muatan politis yang cukup rumit dan mengandung muatan politis yang cukup signifikan, berbeda dengan penyusunan anggaran 
di perusahaan swasta yang muatan politisnya relatif lebih kecil. Mardiasmo (2013:63) menyebutkan beberapa fungsi anggaran dalam managemen organisasi sektor publik sebagai berikut.

1. Anggaran sebagai alat perencanaan

2. Anggaran sebagai alat pengendalian

3. Anggaran sebagai alat kebijakan

4. Anggaran sebagai alat politik

5. Anggaran sebagai alat koordinasi dan komunikasi

6. Anggaran sebagai alat penilaian kinerja

7. Anggaran sebagai alat motivasi

\section{Anggaran Berbasis Kinerja}

Anggaran Kinerja mencerminkan beberapa hal sebagai berikut.

1. Maksud dan tujuan permintaan dana

2. Biaya dari program-program yang diusulkan dalam mencapai tujuan ini.

3. Data kuantitatif yang dapat mengukur pencapaian serta pekerjaan yang dilaksanakan untuk tiaptiap program

Untuk dapat menyusun Anggaran Berbasis Kinerja terlebih dahulu harus disusun rencana strategis (Renstra). Penyusunan rencana strategis dilakukan dengan melibatkan seluruh komponen yang ada di dalam pemerintahan dan masyarakat. Agar sistem dapat berjalan dengan baik perlu ditetapkan beberapa hal yang sangat menentukan yaitu standar harga, tolak ukur kinerja dan standar pelayanan minimal yang ditetapkan berdasarkan peraturan perundang-undangan. Pengukuran kinerja digunakan untuk menilai keberhasilan atau kegagalan pelaksanaan kegiatan/program/kebijakan sesuai dengan sasaran dan tugas yang telah ditetapkan dalam rangka mewujudkan visi dan misi pemerintah daerah. Salah satu aspek yang diukur dalam penilaian kinerja pemerintah daerah adalah aspek keuangan berupa anggaran berbasis kinerja. Untuk melakukan suatu pengukuran kinerja perlu ditetapkan indikator-indikator terlebih dahulu antara lain indicator masuk (input) berupa dana, sumber daya manusia dan metode kerja. Agar input dapat diinformasikan dengan akurat dalam suatu anggaran, maka perlu dilakukan penilaian terhadap kewajarannya. Dalam menilai kewajaran input dengan output yang dihasilkan, peran analisa standar biaya sangat diperlukan. Analisa standar biaya adalah penilaian kewajaran atas beban kerja dan biaya yang digunakan untuk melaksanakan suatu kegiatan.

Ruang lingkup Anggaran Berbasis Kinerja adalah sebagai berikut.

1. Menentukan visi dan misi (yang mencerminkan strategi organisasi), tujuan, sasaran dan target.

2. Menentukan Indikator Kinerja

3. Evaluasi dan pengambilan keputusan terhadap pemilihan dan prioritas program.

4. Analisis Standar Biaya

\section{Pedoman Penyusunan APBD Tahun 2014}

Pedoman Penyusunan Anggaran Pendapatan Belanja Daerah (APBD) Tahun Anggaran 2014 didasarkan pada Peraturan Menteri Dalam Negeri (PERMENDAGRI) No.27 Tahun 2013. Pedoman tersebut berisi beberapa hal-hal pokok dalam penyusunan APBD yaitu sebagai berikut.

1. Sinkronisasi Kebijakan Pemerintah Daerah Dengan Kebijakan Pemerintah

2. Prinsip Penyusunan APBD

3. Kebijakan Penyusunan APBD

4. Teknis Penyusunan APBD

Dalam menyusunan APBD Tahun 2014, pemerintah daerah dan DPRD harus memperhatikan halhal sebagai berikut.

1. Penyusunan RKPD (Akhir Bulan Mei) 
2. Penyampaian Rancangan KUA dan Rancangan PPAS oleh Ketua TAPD kepada kepala daerah (Minggu 1 bulan Juni)

3. Penyampaian Rancangan KUA dan Rancangan PPAS oleh kepala daerah kepada DPRD (Pertengahan bulan Juni)

4. Kesepakatan antara kepala daerah dan DPRD atas Rancangan KUA dan Rancangan PPAS (Akhir bulan Juli)

5. Penerbitan Surat Edaran kepala daerah perihal Pedoman penyusunan RKA-SKPD dan RKAPPKD (Awal bulan Agustus)

6. Penyusunan dan pembahasan RKA-SKPD dan RKA-PPKD serta penyusunan Rancangan Perda tentang APBD (Awal bulan Agustus sampai dengan akhir bulan September)

7. Penyampaian Rancangan Perda tentang APBD kepada DPRD (Minggu 1 bulan Oktober)

8. Pengambilan persetujuan bersama DPRD dan kepala daerah (Paling lambat 1 bulan sebelum tahun anggaran yang bersangkutan)

9. Menyampaikan Rancangan Perda tentang APBD dan Rancangan Perkada tentang Penjabaran APBD kepada MDN/Gub untuk dievaluasi (3 hari kerja setelah persetujuan bersama)

10. Paling lambat 1 bulan sebelum tahun anggaran yang bersangkutan (Paling lama 15 hari kerja setelah Rancangan Perda tentang APBD dan Rancangan Perkada tentang Penjabaran APBD diterima oleh MDN/Gub)

11. Penyempurnaan Rancangan Perda tentang APBD sesuai hasil evaluasi yang ditetapkan dengan keputusan pimpinan DPRD tentang penyempurnaan Rancangan Perda tentang APBD (Paling lambat 7 hari kerja (sejak diterima keputusan hasil evaluasi))

12. Penyampaian Keputusan DPRD tentang penyempurnaan Rancangan Perda tentang APBD kepada MDN/Gub (3 hari kerja setelah keputusan pimpinan DPRD ditetapkan)

13. Penetapan Perda tentang APBD dan Perkada tentang Penjabaran APBD sesuai dengan hasil evaluasi (Paling lambat akhir desember (31 desember))

14. Penyampaian Perda tentang APBD dan Perkada tentang Penjabaran APBD kepada MDN/Gub (Paling lambat 7 hari kerja setelah perda dan Perkada ditetapkan)

\section{Penelitian Terdahulu}

1. Basri (2013) meneliti tentang Analisis Penyusunan Anggaran Dan Laporan Realisasi Anggaran Badan Pemberdayaan Masyarakat dan Pemerintahan Desa Provinsi Sulawesi Utara. Tujuan Untuk Mengetahui proses penyusunan anggaran dan laporan realisasi anggaran pada Badan Pemberdayaan Masyarakat dan Pemerintahan Desa Provisi Sulawesi Utara. Penelitian tersebut menggunakan Metode Deskriptif. Hasil Penelitian menunjukkan bahwa proses penyusunan anggaran Badan Pemberdayaan Masyarakat dan Pemerintahan Desa Kota Kotamobagu telah berdasarkan Peraturan Menteri Dalam Negeri No.13 Tahun 2006 dan No.22 Tahun 2011. Realisasi Anggaran Tahun 2012 sebesar 95,30\%.

2. Korompot (2015) dengan judul Analisis Penyusunan Anggaran Pada Dinas Pendapatan Pengelolaan Keuangan Dan Aset Daerah Kota Kotamobagu Tahun Anggaran 2014. Tujuan dari penelitian ini Untuk mengetahui proses penyusunan anggaran di Dinas Pendapatan Pengelolaan Keuangan Dan Aset Daerah Kota Kotamobagu sudah sesuai dengan Peraturan Menteri Dalam Negeri No.27 tahun 2013. Metode yang digunakan adalah metode deskriptif. Hasil penelitian menunjukkan proses penyusunan anggaran pada Dinas Pendapatan Pengelolaan Keuangan Dan Aset Daerah Kota Kotamobagu tahun anggaran 2014 telah sesuai dengan Peraturan Menteri Dalam Negeri No.27 Tahun 2013 tentang Pedoman penyusunan Anggaran Pendapatan Dan Belanja Daerah Tahun Anggaran 2014.

\section{METODE PENELITIAN}

\section{Jenis Penelitian}

Jenis penelitian yang digunakan adalah penelitian deskriptif yaitu suatu pendekatan penelitian yang membicarakan beberapa kemungkinan untuk memecahkan masalah aktual dengan cara mengumpulkan data, menyusun, mengklarifikasi, dan menganalisis. Dimana peneliti secara langsung 
mendatangi objek penelitian yaitu Kantor Kelurahan Karame Kecamatan Singkil Kota Manado untuk memperoleh data-data dan informasi yang dibutuhkan dalam menganalisis penyusunan anggaran.

\section{Tempat dan Waktu Penelitian}

Penelitian ini dilakukan di Kantor Kelurahan Karame Kecamatan Singkil Kota Manado yang bertempat di Kelurahan Karame Lingkungan 5, Kota Manado, Sulawesi Utara. Adapun waktu penelitian dimulai dari bulan Februari sampai dengan Mei 2016.

\section{Jenis dan Sumber Data}

\section{Jenis Data}

Kuncoro (2013:145) menyatakan bahwa data merupakan sekumpulan informasi yang diperlukan untuk pengambilan keputusan. Jenis data terbagi atas dua bagian yaitu.

1. Data kualitatif adalah data yang bersumber dari lokasi penelitian yang berupa keterangan dan uraian untuk mengadakan analisis dan menyajikannya dalam penelitian melalui teori-teori yang berlaku.

2. Data kuantitatif adalah data terbentuk angka-angka dan tabel-tabel kemudian melakukan uraian dan penafsiran dalam data-data tersebut.

Adapun data yang digunakan dalam penelitian ini adalah data kuantitatif.

\section{Sumber Data}

Menurut Kuncoro (2013: 148) data dikelompokkan menjadi dua, yaitu sebagai berikut.

1. Data primer adalah data yang diperoleh dengan survey lapangan yang menggunakan semua metode pengumpulan data original.

2. Data sekunder adalah data yang dikumpulkan oleh pengumpul data dan dipublikasikan kepada masyarakat pengguna data.

Sumber data yang digunakan dalam penelitian ini adalah data sekunder.

Data sekunder dalam penelitian ini terdiri dari berikut ini.

1. Data berupa dokumen-dokumen penyusunan anggaran yang dapat digunakan untuk menganalisis penyusunan anggaran.

2. Buku-buku literatur, dan jurnal-jurnal penelitian sebelumnya yang berhubungan dengan penelitian ini.

\section{Prosedur Penelitian}

Prosedur penelitian ini meliputi langkah-langkah sebagai berikut.

1. Perumusan Masalah

2. Pengumpulan Data

3. Analisis Data

4. Penarikan Kesimpulan

\section{Metode Pengumpulan Data}

Salah satu kegiatan dalam penelitian ini adalah merumuskan metode pengumpulan data sesuai dengan masalah yang diteliti. Metode yang digunakan dalam penelitian ini adalah studi lapangan. Metode ini digunakan untuk mengetahui seberapa jauh kesesuaian antara teori yang digunakan dengan keadaan yang sebenarnya dari objek yang diteliti. Dalam studi lapangan ini menggunakan dua cara yaitu sebagai berikut.

1. Wawancara langsung, yaitu dengan melakukan percakapan langsung serta tanya jawab dengan pihak Kantor Kelurahan Karame Kecamatan Singkil Kota Manado 
2. Studi dokumentasi, dilakukan dengan melakukan penelusuran terhadap dokumen-dokumen yang mendukung penelitian ini, seperti penyusunan anggaran.

\section{Metode Analisis}

Mertode analisis yang digunakan dalam penelitian ini adalah metode analisis deskriptif, yaitu dengan langkah mengumpulkan dan menyaring keterangan-keterangan yang diperoleh secara menyeluruh dan detail, kemudian diuraikan sehingga diperoleh gambaran yang jelas. Adapun datadata yang diperoleh berupa proses penyusunan anggaran yang selanjutnya dilihat kesesuaiannya dengan Peraturan Menteri Dalam Negeri nomor 27 tahun 2013 tentang pedoman penyusunan anggaran pendapatan belanja daerah tahun anggaran 2014, kemudian dianalisis penerapannya sehingga dapat ditarik suatu kesimpulan.

\section{HASIL PENELITIAN DAN PEMBAHASAN}

\section{Kota Manado}

Kota Manado terletak di ujung jazirah utara pulau Sulawesi, pada posisi geografis 124 54'BT dan $130^{\prime}-140^{\prime} \mathrm{LU}$. Iklim di kota ini adalah iklim tropis dengan suhu rata-rata $24-27 \mathrm{C}$. Curah hujan rata-rata $3.187 \mathrm{~mm} /$ tahun dengan iklim terkering di sekitar bulan Agustus dan terbasah pada bulan Januari. Intensitas penyinaran matahari rata-rata 53\% dan kelembaban 84\%. Luas wilayah daratan adalah 15.726 hektare. Manado juga merupakan kota pantai yang memiliki garis pantai panjang $18,7 \mathrm{~km}$. Kota ini juga dikelilingi oleh perbukitan dan barisan pegunungan. Wilayah daratannya didominasi oleh kawasan berbukit dengan sebagian daratan rendah di daerah pantai. Interval ketinggian daratan antara 0-40\% dengan puncak tertinggi digunung Tumpa. Wilayah perairan Kota Manado meliputi pulau Bunaken, pulau Siladen dan pulau ManadoTua.

\section{Kantor Kelurahan Karame Kecamatan Singkil Kota Manado}

Terbentuknya desa Karame tahun 1978 dimekarkan dari Wawonasa dengan Kepala Desa Bpk. Haruna. Nama Karame diambil dari bahasa Sangihe yang berarti ramai dan Desa Karame ditunjuk Kepala Desa oleh Wali kota A.A Pelealu pada tanggal 29 maret 1978 yaitu Zeth Walo.

Struktur Organisasi Kantor Kelurahan Karame Kecamatan Singkil Kota Manado

1. Lurah

2. Sekertaris Lurah

3. Kepala Seksi Tata Pemerintahan

4. Kepala Seksi Pemberdayaan Masyarakat

5. Kepala Seksi Ketentraman dan Ketertiban

6. Kepala Seksi Pelayanan Umum

\section{Hasil Penelitian}

Penyusunan anggaran di Kantor Kelurahan Karame Kecamatan Singkil Kota Manado dimulai dari pengumpulan data dari bidang mengenai program/kegiatan yang akan dilaksanakan di tahun 2014 . Program/kegiatan yang disusun setiap bidang didasarkan pada Rencana Strategis (RENSTRA) Kantor Kelurahan Karame Kecamatan Singkil Kota Manado yang memberikan gambaran dan arahan kebijakan serta strategi pembangunan pada tahun anggaran 2014 sebagai tolak ukur dan alat bantu dalam melaksanakan tugas dan fungsi Kantor Kelurahan Karame Kecamatan Singkil Kota Manado. Tahapan penyusunan anggaran satuan kerja pemerintahan daerah adalah sebagai berikut.

\section{Rencana Kerja Pembangunan Daerah (RKPD)}

Data dari setiap bidang akan dituangkan dalam Rencana Kerja Kantor Kelurahan Karame Kecamatan Singkil Kota Manado. Rencana Kerja Pembangunan Daerah (RKPD) merupakan 
penjabaran RPJMD untuk 1 (satu) tahun. Renja mempunyai fungsi penting dalam sistem perencanaan daerah karena Renja menerjemahkan perencanaan strategis jangka menengah (RPJMD dan Renstra SKPD) ke dalam rencana program dan penganggaran tahunan. Renja menjembatani sinkronisasi dan harmonisasi rencana strategis dalam langkah-langkah tahunan yang konkrit dan terukur.

Renja Kantor Kelurahan Karame Kecamatan Singkil Kota Manado merupakan dokumen perencanaan untuk 1 (satu) tahun periode yang memuat program dan kegiatan pembangunan yang dilaksanakan oleh pemerintah maupun yang ditempuh dengan mendorong partisipasi masyarakat. Sebagai dokumenresmi pemerintah daerah Renja dan RKPD mempunyai kedudukan yang strategis yaitu menjembatani antara perencanaan strategis ke dalam rencana regional dengan memuat kebijakan pembangunan, prioritas pembangunan, rancangan kerangka ekonomi daerah dan program kegiatan SKPD sebagai rencana operasional RKPD yang merupakan pedoman dalam penyusunan kebijakan umum anggaran (KUA) dan prioritas plafon anggaran sementara (PPAS).

\section{KUA dan PPAS}

Kebijakan Umum APBD (KUA) adalah sasaran dan kebijakan daerah dalam satu tahun anggaran yang menjadi petunjuk dan ketentuan umum yang disepakati sebagai pedoman penyusunan R-APBD dan RP-APB Program dan Kegiatan Tahun 2014. Program dan kegiatan yang sumber pembiayaan dari APBD ada 8 Program Strategis yaitu sebagai berikut.

1. Program Pelayanan Administrasi Perkantoran

2. Program Peningkatan Sarana dan Prasaran Aparatur

3. Program Peningkatan Disiplin Aparatur

4. Program Peningkatan Kapasitas Sumber Daya Aparatur

5. Program Peningkatan Kapasitas Aparatur Pemerintah Desa

6.Program Perencanaan Pembangunan Daerah

7.Program Penanganan Bencana

8. Program Peningkatan Pelayanan Kepada Masyarakat

Prioritas dan Plafon Anggaran Sementara (PPAS) adalah jumlah rupiah batas tertinggi yang dapat dianggarkan oleh tiap-tiap satuan kerja perangkat daerah, termasuk di dalamnya belanja pegawai. Plafon anggaran yang disepakati oleh Pemerintah Daerah dengan DPRD bersifat sementara dalam arti bahwa plafon anggaran harus ditindak lanjuti dengan Peraturan Kepala Daerah menyangkut batasan plafon anggaran yang bersifat tetap/Prioritas dan Plafon Anggaran (PPA) SKPD. Prioritas Plafon Anggaran (PPA) yang telah ditetapkan selanjutnya dijadikan pedoman dalam penyusunan rencana anggaran SKPD pada masing-masing SKPD.

\section{Rencana Kerja Anggaran Satuan Kerja Perangkat Daerah (RKA-SKPD)}

KUA/PPAS yang telah disepakati antara Kepala Daerah dan DPRD (Nota Kesepakatan) selanjutnya dibuat Surat Edaran Kepala Daerah tentang Pedoman Penyusunan RKA-SKPD. Dalam Surat Edaran Kepala Daerah memuat hal-hal berikut.

1. PPA yang dialokasikan untuk setiap program SKPD berikut rencana pendapatan dan pembiayaan.

2. Sinkronisasi program dan kegiatan antar SKPD dan kinerja SKPD berkenaan sesuai standar pelayanan minimal yang ditetapkan.

3. Batas waktu penyampaian RKA-SKPD kepada PPKD.

4. Hal-hal lainnya yang perlu mendapat perhatian SKPD terkait dengan prinsip-prinsip peningkatan efisiensi, efektifitas, transparansi, dan akuntabilitas penyusunan anggaran dalam rangka pencapaian prestasi kerja.

5. Dokumen sebagai lampiran meliputi KUA, PPA, kode rekening APBD, format RKA-SKPD, analisis standar belanja dan standar satuan harga.

Terdapat beberapa hal yang terkait dengan RKA-SKPD yaitu sebagai berikut.

1. Aspek dan Dimensi RKA-SKPD

2.Pedoman Penyusunan RKA-SKPD

3.Rancangan Anggaran Kinerja 


\section{Dokumen Pelaksanaan Anggaran Satuan Kerja Perangkat Daerah (DPA-SKPD)}

Dalam proses menyusun anggaran Kantor Kelurahan Karame yang menyusun Rencana Kerja Anggaran Satuan Kerja Perangkat Daerah (RKA-SKPD) yang kemudian diinput kepada Pemerintah Kota Manado untuk menyusun Dokumen Pelaksanaan Anggaran Satuan Kerja Perangkat Daerah (DPA-SKPD).

Dokumen Pelaksanaan Anggaran Satuan Kerja Perangkat Daerah (DPA-SKPD) merupakan dokumen yang memuat pendapatan, belanja dan pembiayaan yang digunakan sebagai dasar pelaksanaan anggaran oleh pengguna anggaran.

Dalam DPA-SKPD Kantor Kelurahan Karame Kecamatan Singkil Kota Manado terdapat 8 program/kegiatan sebagai berikut.

1. Program Pelayanan Administrasi Perkantoran

2. Program Peningkatan Sarana dan Prasarana Aparatur

3. Program Peningkatan Disiplin Aparatur

4. Program Peningkatan Kapasitas Sumber Daya Aparatur

5. Program Peningkatan Kapasitas Aparatur Pemerintah Desa

6. Program Perencanaan Pembangunan Daerah

7. Program Penanganan Bencana

8. Program Peningkatan Pelayanan Kepada Masyarakat

Dari 8 program/kegiatan pada Kantor Kelurahan Karame Kecamatan Singkil Kota Manado, 7 program/kegiatan sudah terealisasi dengan baik tetapi ada 1 program yang ditiadakan oleh Pemerintah Kota Manado.

\section{Pembahasan}

Penyusunan APBD tahun 2014 pada Kantor Kelurahan Karame Kecamatan Singkil Kota Manado telah sesuai dengan Peraturan Menteri Dalam Negeri Nomor 27 tahun 2013 tentang Pedoman Penyusunan Anggaran Pendapatan dan Belanja Daerah Tahun Anggaran 2014 mulai dari penyusunan Rencana Kerja Pemerintah Daerah (RKPD), KUA/PPAS sampai dengan Rencana Kerja Anggaran Satuan Kerja Perangkat Daerah (RKA-SKPD) kemudian disajikan kedalam Dokumen Pelaksanaan Anggaran Satuan Kerja Perangkat Daerah (DPA-SKPD). Penelitian terdahulu yang dilakukan oleh Basri, (2013) yaitu Analisis Penyusunan Anggaran dan Laporan Realisasi Anggaran pada Badan Pemberdayaan Masyarakat dan Pemerintahan Desa Provinsi Sulawesi Utara dan penelitian terdahulu yang dilakukan oleh Sulistio, (2010) yaitu Proses Penyusunan Anggaran Kinerja (Studi pada Pemerintah Kabupaten Way Kanan) dan Korompot (2015) yaitu Analisis Penyusunan Anggaran Pada Dinas Pendapatan Pengelolaan Keuangan dan Aset Daerah Kota Kotamobagu Tahun Anggaran 2014 dijadikan sebagai acuan untuk lebih terperinci dalam membahas proses penyusunan anggaran yang sesuai dengan Permendagri terbaru. Berikut ini jadwal penyusunan APBD Kantor Kelurahan Karame Kecamatan Singkil Kota Manado Tahun Anggaran 2014.

1. Penyusunan RKPD (Akhir bulan Mei)

2. Penyampaian Rancangan KUA dan PPAS oleh Ketua TAPD kepada Kepala Daerah (Awal bulan Juni)

3. Penyampaian Rancangan KUA dan PPAS oleh Kepala Daerah kepada DPRD (Pertengahan bulan Juni)

4. Kesepakatan antara Kepala Daerah dan DPRD atas rancangan KUS dan PPAS (Akhir bulan Juli)

5. Penerbitan surat edaran Kepala Daerah perihal pedoman penyusunan RKA-SKPD (Awal bulan Agustus)

6. Penyusunan dan pembahasan RKA-SKPD serta penyusunan rancangan Perda tentang APBD kepada DPRD (Awal bulan Agustus sampai dengan akhir bulan September)

7. Penyampaian rancangan perda tentang APBD kepada DPRD (Awal bulan Oktober)

8. Pengambilan persetujuan bersama DPRD dan Kepala Daerah (paling lambat sebelum tahun anggaran yang bersangkutan) 
9. Menyampaikan rancangan perda tentang APBD dan rancangan perkada tentang penjabaran APBD kepada Menteri Dalam Negeri/Gub untuk dievaluasi (3 hari kerja setelah persetujuan bersama)

10. Hasil evaluasi rancangan perda tentang APBD dan rancangan perkada tentang penjabaran APBD (paling lambat 15 hari kerja setelah rancangan perda dan rancangan perkada tentang APBD diterima oleh Menteri Dalam Negeri/Gub)

11. Penyempurnaan Rancangan Perda tentang APBD sesuai hasil evaluasi yang ditetapkan dengan keputusan pimpinan DPRD tentang penyempurnaan Rancangan Perda tentang APBD (Paling lambat 7 hari kerja (sejak diterima keputusan hasil evaluasi))

12. Penyampaian Keputusan DPRD tentang penyempurnaan Rancangan Perda tentang APBD kepada Menteri Dalam Negeri/Gub (3 hari kerja setelah keputusan pimpinan DPRD ditetapkan)

13. Penetapan Perda tentang APBD dan Perkada tentang Penjabaran APBD sesuai dengan hasil evaluasi (Paling lambat akhir Desember (31 Desember))

14. Penyampaian Perda tentang APBD dan Perkada tentang Penjabaran APBD kepada Menteri Dalam Negeri/Gub (Paling lambat 7 hari kerja setelah perda dan Perkada ditetapkan)

Hasil penelitian yang diperoleh, kemudian dibandingkan dengan peraturan yang berlaku, penyusunan anggaran pada Kantor Kelurahan Karame Kecamatan Singkil Kota Manado tahun anggaran 2014 telah sesuai dengan Permendagri No. 27 Tahun 2013 yang meliputi tahapan mulai dari penyusunan RKPD, KUA/PPAS hingga RKA SKPD dengan baik sehingga dapat menyusun Dokumen Pelaksanaan Anggaran Satuan Kerja Perangkat Daerah (DPA-SKPD). Penyusunan anggaran pada Kantor Kelurahan Karame Kecamtan Singkil Kota Manado sudah disajikan dalam bentuk siklus anggaran daerah. Kiranya diharapkan pada penyusunan anggaran di tahun selanjutnya, Kantor Kelurahan Karame Kecamatan Singkil Kota Manado harus lebih baik lagi dalam menyusun anggaran tahun selanjutnya, agar dapat menyajikan Dokumen Pelaksanaan Anggaran Satuan Kerja Perangkat Daerah (DPA-SKPD) yang efisien dan efektif. Untuk itu, Kantor Kelurahan Karame Kecamatan Singkil Kota Manado lebih banyak mengikuti sosialisasi dan bimbingan teknis kepada para pegawainya yang tidak hanya bertujuan untuk meningkatkan kualitas SDM namun juga dapat menghasilkan RKA-SKPD yang transparan, efisien dan efektif demi tujuan pembangunan dan kesejahteraan masyarakat.

\section{PENUTUP}

\section{Kesimpulan}

Berdasarkan hasil penelitian dan pembahasan pada bab sebelumnya maka dapat ditarik kesimpulan bahwa:

1. Kantor Kelurahan Karame Kecamatan Singkil Kota Manado dalam pelaksanaan penyusunan anggaran tahun anggaran 2014 telah sesuai dengan Permendagri No.27 Tahun 2013.

2. Pelaksanaan penyusunan anggaran Kantor Kelurahan Karame Kecamatan Singkil Kota Manado tahun anggaran 2014 meliputi penyusunan RKPD, KUA/PPAS hingga RKA SKPD dengan baik.

3. Penyusunan Anggaran pada Kantor Kelurahan Karame Kecamatan Singkil Kota Manado sudah disajikan dalam bentuk siklus anggaran.

4. Dari 8 program/kegiatan pada Kantor Kelurahan Karame Kecamatan Singkil Kota Manado, 7 program sudah terealisasi dengan baik tetapi ada 1 program yang ditiadakan oleh Pemerintah Kota Manado.

\section{Saran}

Saran yang dapat diberikan dari hasil penelitian ini yang dapat dijadikan bahan masukan dan perbaikan bagi Kantor Kelurahan Karame Kecamatan Singkil Kota Manado, sebagai berikut:

1. Kiranya diharapkan pada penyusunan anggaran di tahun selanjutnya, Kantor Kelurahan Karame Kecamatan Singkil Kota Manado harus lebih baik lagi dalam menyusun anggaran tahun selanjutnya, agar dapat menyajikan Dokumen Pelaksanaan Anggaran Satuan Kerja Perangkat Daerah (DPA-SKPD) yang efisien dan efektifitas. 
2. Kantor Kelurahan Karame Kecamatan Singkil Kota Manado lebih banyak mengikuti sosialisasi dan bimbingan teknis kepada para pegawainya yang tidak hanya bertujuan untuk meningkatkan kualitas SDM namun juga dapat menghasilkan DPA-SKPD yang transparan, efisien dan efektif demi tujuan pembangunan dan kesejahteraan masyarakat.

\section{DAFTAR PUSTAKA}

Basri, Ramlah. 2013. Analisis Penyusunan Anggaran Dan Laporan Realisasi $\quad$ Anggaran Pada BPM-PD Provinsi Sulawesi Utara. Skripsi. Universitas Samratulangi. Manado. Jurnal Vol.1 No.4. (2013) http://ejournal.unsrat.ac.id/index.php/emba/article/view/2651/2204. Diakses pada 4 Desember 2013. Hal. 202-212..

Deddi, Iswahyudi, Maulidah. 2012. Akutansi Pemerintahan. Salemba Empat, Jakarta.

Hariadi Pramono, Yanuar E. Restianto dan Icuk Rangga Bawono. 2010. Pengelolaan Daerah. Penerbit Salemba Empat, Jakarta.

Kementrian Dalam Negeri. 2013. Peraturan Menteri Dalam Negeri Nomor 27 Tahun

Keuangan Tentang Pedoman Penyusunan APBD Tahun 2014. Jakarta.

Korompot, Riska. 2015. Analisis Penyusunan Anggaran Pada Dinas Pendapatan Pengelolaan Keuangan Dan Aset Daerah Kota Kotamobagu Tahun Anggaran 2014. Skripsi. Universitas Samratulangi. Manado. Jurnal EMBA. Vol.3 No.1. (2015) http://ejourmal.unsrat.ac.id/index.php/emba/article/view/7612. Diakses pada 26 April 2015. Hal 841-950

Mardiasmo. 2013. Akuntansi Sektor Publik. Andi. Yogyakarta.

Peraturan Pemerintah No. 71 Tahun 2010 Tentang Standar Akuntansi Pemerintahan Berbasis Akrual.

Suwardjono. 2013. Teori Akuntansi Perekayasaan Pelaporan Keuangan. Edisi Ketiga. BPFE, Yogyakarta.

Nordiawan Deddi dan Ayunyngtias Hertianti. 2010. Akuntansi Sektor Publik. Salemba Empat. Jakarta.

Republik Indonesia. 2004. Undang-Undang Nomor 32 Tahun 2004 Tentang

Pemerintah Daerah. Republik Indonesia. 2003. Undang-Undang Nomor 17 Tahun 2003 Tentang Kuncoro. 2013 